\title{
Diasporans dialektik: \\ Om konsten att vara judisk i den svenska moderniteten
}

\section{LARS DENCIK}

Judarna i Sverige utgör en etnisk och kulturell minoritet som har bevarat och utvecklat ett särskilt »judiskt " förhållningssätt till tillvaron. I denna artikel perspektiveras vad "ett judiskt förhållingssätt "bygger på och innebär. Utifrån det frågas hur den specifika judiska tanketraditionen, dess uppfattning av begreppen religion och folktillhörighet, och i synnerhet predikamentet att leva som minoritet $i$ diasporan samverkat till att den judiska gruppen i dag på en och samma gång kan vara en distinkt nationell minoritet $i$

Sverige och väl integrerade i det moderna samhället.

"Jakten efter kunskap för dess egen skull, en nästan fanatisk kärlek till rättvisan och en önskan ompersonlig frihet - det är detta som gör att jag tackar min stjärna att jag tillhör dennagemenskap."

Albert Einstein om sin förankring i den judiska traditionen.

Lars Dencik, professor i socialpsykologi, Institut for Psykologi og Uddannelsesforskning, Roskilde universitet, Danmark.

\section{Religion och folktillhörighet}

Att vara jude innebär att höra till en särskild etnisk kategori - ett folk med en särskild historia, särskilda kulturella traditioner, sedvänjor och språk.

Judendom är en religion, men en religion som i ett avgörande socialt avseende skiljer sig från de andra s.k. abrahamitiska religioner som finns företrädda i vår del av världen: kristendom och islam är inte förbundna med en speciell folktillhörig- 
het. Kristendomen förutsätter inte att en kristen är t.ex. svensk. En kristen kan lika gärna vara dansk, engelsman, tysk, amerikan eller t.ex. palestinier. Islam förutsätter heller inte att en muslim är t.ex. arab - några araber är kristna och de flesta muslimer är inte araber. ${ }^{1}$ Men den som har judendom som religionstillhörighet är alltid också jude i betydelsen att vara en i det judiska folket. Och den som hör till det judiska folket har alltid judendom som sin religion - även om hon eller han inte är ett dugg religiös. Det låter sig t.ex. utan vidare sägas att man är en judisk ateist ${ }^{2}$ eller »sekulär jude» ${ }^{3}$. Däremot är det närmast ett contradictio in adjecto att säga

1 Utan t.ex. pakistanier, indonesier, turkar eller malajer (från Malaysia). Inom islam finns dock begreppet Umma som en sammanfattande term för de människor som tillsammans utgör den muslimska världen.

2 Så beskriver t.ex. forskaren och författaren Georg Klein sig själv i boken Ateisten och den heliga staden (1987). Den franske filosofen André Comte-Sponville har fångat ett för många moderna judar ganska typisk förhållningssätt i följande yttrande: „Jag är trogen ateist, eftersom jag inte tror på någon Gud; trogen, därför att jag erkänner min tillhörighet till en viss tradition, och till vissa värden som vi ärvt från våra förfäder."

3 Något fler än var tredje medlem i en judisk församling i Sverige anger att de antingen inte alls utövar religionen eller att »jag är judisk bara så där i allmänhet». Om man till detta skulle lägga det minst lika stora antal judar i Sverige som valt att inte vara medlem i någon judisk församling skulle med all säkerhet andelen »sekulära judar» omfatta betydligt fler än hälften av alla judar i Sverige, se Lars Dencik \& Karl Marosi: Judiskt liv i Sverige, Judiska Centralrådet, Stockholm 2007. att någon är »kristen ateist» eller »sekulär muslim».

De flesta judar i världen idag lever, i diasporan ${ }^{4}$, dvs. som ett folk bland andra folk. ${ }^{5}$ Dvs. de utgör en etnisk/religiös/kulturell minoritet $\mathrm{i}$ ett land där majoriteten och makthavarna i samhället inte delar deras ursprung, historia, religiösa orientering och/eller kulturella sedvänjor. Detta gäller inte minst i Sverige där den judiska gruppen i Sverige enligt lag sedan den 1 april år 2000 utgör en av Sveriges fem officiellt erkända nationella minoriteter. ${ }^{6}$ Att leva i diasporan innebär att delar av ens livsperspektiv, ideosynkrasier och speciella sensibilitet i förhållande till olika begivenheter i samhället på något sätt skiljer sig från majoritetsbefolkningens. En jude i diasporan kan vara t.ex. amerikan, fransman, argentinare, ungrare eller svensk. Men aldrig "bara» det. Hon eller han är alltid också och samtidigt "jude» - vad man så lägger i det.

I motsats till t.ex. kristendomen och

4 Ordet diaspora härstammar från det grekiska verbet speiro (att så) och prepositionen dia (över). I mänskliga sammanhang syftar det ursprungliga grekiska ordet diaspora till migration och att ett folk, som t.ex. det judiska, lever "utspritt bland folkslagen". Det hebreiska ordet galut betecknar samma fenomen, att man lever i exil (eg. "utanför hemlandet"), men har klarare negativa konnotationer än det grekiska diaspora.

5 För att göra det ännu tydligare: att tala om en kristen eller muslimsk diaspora ger knappast mening, däremot är »den judiska diasporan" ett välkänt historiskt och sociologiskt fenomen.

6 De fyra andra av Sveriges officiellt erkända nationella minoriteter är samerna, romerna, sverige-finnarna och tornedalingarna. 
islam är judendom inte en missionerande religion - den betecknas ibland som en "stamreligion". En person som inte är född som jude kan dock efter rabbinsk prövning konvertera till judendomen. En konvertering till judendomen är fråga om mycket mer än »bara» att välja sig en religiös "tro». För den enskilde är det att konvertera till judendom - rabbiner är generellt restriktiva och initialt avvisande - i princip och också rent konkret fråga om en grundläggande mental och social omställning. ${ }^{7}$ För det handlar inte renodlat om "religion" - ett västerländskt begrepp som inte har någon exakt motsvarighet i hebreiskan - utan i lika hög grad om att bli en del av det judiska folket (på hebreiska: am jisrael), dvs. att komma att dela dess traditioner, historia, (över)känslighet och livsperspektiv. Kort sagt att i någon mening vara "judisk» i sitt förhållningssätt.

När de judar som valt att registrera sig som medlemmar i de judiska församling-

7 Det prototypiska fallet är bibelns berättelse om Rut (Rut 1:16-17). De flesta som konverterar till judendom har en personlig anknytning till judiska förhållanden, t.ex. genom att vara barn till en judisk far (men inte en judisk mor), eller genom att leva tillsammans med en judisk partner. Sedan någon konverterat till judendom skall detta att hon eller han är »konvertit« i inget judiskt sammanhang tillmätas någon betydelse eller ens nämnas. Beräkningar gjorda utifrån det material jag tillsammans med Karl Marosi insamlat i den enkätundersökning vi runt millennieskiftet gjorde bland medlemmarna i de judiska församlingarna i Sverige (under åren 2000-2003 successivt redovisat i tidskriften Judisk Krönika) visar att något över tio procent av medlemmarna har blivit judar genom att konvertera till judendom. arna i Sverige, som tidigare benämndes "Mosaiska församlingar», i början av 2000talet tillfrågades om hur de betraktar den judiska gruppen i Sverige angav färre än var tjugonde av dem (4,5 procent) att de ser den judiska gruppen i Sverige "primärt som en religiös grupp" medan ett mycket stort flertal, ungefär 2/3 (65,3 procent) av medlemmarna i dessa judiska församlingar, ser den judiska gruppen i Sverige "primärt som en del av det judiska folket (Dencik \& Marosi 2007).

Vad är bakgrunden för det? Hur kan det komma sig att man, trots att man lever i världens modernaste och också världens mest sekulariserade land (Pettersson \& Esmer 2008), i den demokrati i världen som mer systematiskt än något annat har institutionaliserat individualism (Berggren \& Trägårdh 2006), som mer än andra är inriktat på att det skall råda jämställdhet mellan olika grupper i samhället, ett land som antagit fler lagar och konventioner mot all slags diskriminering än de flesta andra och som också kraftfullare än de flesta går in för att skydda medborgarnas lika och mänskliga rättigheter - att judar i ett sådant land, judar som i långa stycken delar dessa värderingar, fortfarande upplever sig som en etniskt särskild grupp och utifrån det utvecklar ett särskilt »judiskt» förhållningssätt?

I denna artikel vill jag mot denna bakgrund försöka utreda två sammanhängande frågeställningar:

Vad i judendomen och det judiska folkets kulturarv har varit särskilt avgörande för att det judiska folket har kunnat bevara och utveckla sina kulturella traditioner samti- 
digt som man blivit en väl integrerad del $i$ det moderna samhället?

Vad innebär det för ett folk som det judiska att man lever i en diaspora? Och mera speciellt: vad betyder detta för det förhaillningssätt man utvecklar till samhällets makthavare och samhällelig maktutövning mer generellt?

Analysen bygger dels på egna empiriska undersökningar av identitet, levnadsvanor och attityder bland medlemmarna i de judiska församlingarna i Sverige idag (Dencik \& Marosi 2007) samt på andra studier av judiskt liv och tänkande i dagens värld (bl.a. Bredefeldt 2008, Fisher 1996, Gitelman et al. 2003, Goldscheider \& Zuckerman 1984, Gruber 2002, Jakubowski 1993, Lustig \& Leveson 2006, Schnapper 1980).

\section{Förutsättningar för nett judiskt förhållningssättı}

Plus ça change, plus c'est la même chose - ju mera det förändrar sig, desto mer förblir det samma sak. I en värld kännetecknad av snabba förändringar blir det att inte ändra sig synonymt med att döma sig själv till att bli otidsenlig, gammalmodig, överspelad, obsolet.

Att bevara sin identitet och överleva som kultur består ur den synpunkten $\mathrm{i}$ konsten att förändra sig för att förbli densamme.

I ljuset av den insikten kan man betrakta den judiska gruppens väg till kulturell överlevnad. Judendom är en av världens äldsta ännu praktiserade religioner och judenheten en av de etniciteter som längst varit känd som sådan. Till skillnad från många andra av historiens religioner och etniciteter har judendomen och judenheten varken uppgått $i$ andra trosföreställningar och folk eller - trots aktningsvärda försök till det blivit utrotad. Mot bakgrund av det skall vi i det följande närma oss frågan om det finns ett specifikt »judiskt» förhållningssätt till makt, utsatthet och överlevnad som kan förklara detta?

Vad kan då menas med nett judiskt förhållningssättu? Av det att man är född som jude följer inte automatiskt att man förhåller sig "judiskt». Inte heller är det att "förhålla sig judiskt" identiskt med att ha judendom som sin religion - några av dem som mest ihärdigt och trosvisst framställer sig själva som judendomens, alltså den judiska religionens, företrädare på jorden, t.ex. några av dem som är s.k. bosättare på Västbanken, kännetecknas just av att inte förhålla sig njudiskt». Man kan alltså både vara född jude och religiös jude utan att för den skull ha vad jag här vill beteckna som ett ıjudiskt förhållningssätt» - även om nog de flesta som definierar sig själva som judar i diasporan i större eller mindre grad har ett sådant förhållningssätt.

Ett judiskt förhållningssätt är snarare kulturellt än genetiskt och/eller religiöst betingat: det hänger samman med i vilken grad individens eller gruppens livsperspektiv och levnadssätt baserar sig på de historiska erfarenheter judar som ett folk gjort genom dess 2000-åriga diasporahistoria. Starten på denna historia har fortfarande djup symbolisk innebörd: strax före det dåvarande centrat $\mathrm{i}$ judiskt liv, templet $\mathrm{i}$ 
Jerusalem förstördes av de romerska erövrarna, lät sig en av den judiska nationens ledanda lärde - »intellektuelle» skulle vi säga med dagens språkbruk - Jochanan Ben Zackai - smugglas ut ur den belägrade staden i en kista. ${ }^{8}$ Inne i staden härskade zeloterna, den politiska fraktion bland de belägrade judarna som förordade att föra krig. Jochanan Ben Zackai hade insett att den vägen skulle föra till både stadens och folkets och därigenom judendomens ödeläggelse och undergång. Genom att ta sig ut ur staden och ta med sig sin kunskap, den judiska läran och traditionen ut $i$ »förskingringen" skulle denna däremot kunna överleva. Jochanan slog sig ned i den lilla staden Javne och grundade där världens första judiska akademi (jeshiva) och lade därmed fundamentet till judendomens överlevnad. "Sensmoralen i den här historien" skriver Jackie Jakubowski i inledningen till sin bok Spår av lamed (2009) blev för diasporans judar natt det ligger mer styrka i kunskap än i fysisk makt». I den judiska diasporans första akademi formulerades principerna för det judiska livet utanför landet Israel - hur tradition och kulturell särart skulle vidareföras i samspel med ett omgivande icke-judiskt samhälle.

För zeloterna i det belägrade och snart besegrade Jerusalem framstod Jochanan som desertör och förrädare. Men i Talmud, den stora och viktigaste efterbibliska judiska samling av lärda diskussioner, kommentarer och bibeltolkningar (mer härom nedan) är

8 Den romerska belägringen tillät ingen levande jude att lämna staden - endast döda kunde föras ut ur staden för att begravas. det Jochanan Ben Zackais pragmatism och samförståndssträvan som hyllas och bildar rättesnöret. Jakubowski sammanfattar:

"Det som karakteriserar Jochanan Ben Zackais, och Talmuds, förhållningsmönster är tonvikten på kunskapens betydelse. Men också pragmatism och en insikt om att samarbete och kompromissande med en - ibland fientlig - omgivning, snarare än soldater och en hopplös väpnad kamp, pa längre sikt garanterar judisk överlevnad.

Det är anmärkningsvärt med vilken konsekvens Javnemodellen varit gällande $i$ den judiska diasporan under de senaste tvåtusen åren.» (Jakubowski ibid. s. 10-11).

En implikation av detta har varit att man i den judiska lärdomstraditionen vinnlagt sig om att tolka och fortsatt och ständigt nytolka den judiska traditionens och grundläggande judiska texters innebörder utifrån sin samtids villkor.

Inom den judiska texttolkningstraditionen tas textens yta aldrig för given. Här möter vi alltid flera olika lärde som diskuterar den, borrar sig ner under ytan på den, frågar sig: vad betyder detta? Varför står det på detta viset? De som frågar och föreslår olika svar eller tolkningar är givetvis inte överens - då skulle de varken kunna eller behöva föra denna ständigt fortgående debatt. Talmud består just av argumenteringar för alternativa och ofta motstridiga tolkningar av olika textavsnitt. ${ }^{9}$ Just i detta,

\footnotetext{
9 Shamai och Hillel är två av Talmuds mest välkända trätobröder.
} 
i det öppna accepterandet av oenighet, i ifrågasättandet av varje oomstridd auktoritet (inkl. Gud), har vad man med en överdrivet högtidlig term skulle kunna kalla "det judiska tänkandet» sin utgångspunkt. Snarare än att mana till att följa tropp stöttar det modet att vara avvikande, snarare än att leda till lydnad uppfordrar det till att reflektera.

Det är i kraft av detta, det ständiga reflekterandet, som den judiska traditionen har förblivit en levande tradition. Insikten här är att traditioner förs vidare genom historien - inte genom att förbli och betyda detsamma oavsett samhällssituation, som fundamentalister av olika observans inbillar sig, utan tvärtom genom att öppna sig för och ta till sig de ständigt nya villkor som man, t.ex. som jude, lever under. Det är genom kommentarer som tar sin utgångspunkt i ens egen upplevda verklighet och nya tolkningar av ibland urgamla texter som en tradition på en och samma gång kan hållas levande och förändras. Det till synes paradoxala inträffar då att den kulturella traditionen, i detta fall den judiska, bevaras genom att ständigt förändras. Traditionen är ju, som Harold Bloom, den judisk-amerikanske litteraturteoretikern, en gång har sagt, den förklädnad av kontinuitet som kulturella förändringar ikläder sig. ${ }^{10}$ Eller med andra ord: förutsättningen för att en tradition skall kunna hållas levande är att den kan vara ett dynamiskt svar på historiens gång. Walter Benjamin, en av

10 Citerat från Robert Alter: Necessary Angels. Tradition and Modernity in Kafka, Benjamin and Sholem, 1991, p. 89. mellankrigstidens av judiskt tänkande präglade europeiska intellektuella, formulerade strax före sin död år 1940, när han försökte undkomma nazismens judeförföljelser ${ }^{11}$, följande tes: Varje epok måste på nytt försöka vrida loss traditionen från den konformism som alltid hotar att ta den i besittning. ${ }^{12}$ Som han och hans näre vän och intellektuelle sparringpartner Gershom Sholem ${ }^{13}$ såg det, innehåller varje text många förborgade sanningar som bara kan utvinnas genom de kommentarer till texten som varje ny historisk situation kräver. På det sättet har den judiska traditionen att ständigt på nytt kommentera en texturkund i själva verket blivit en kraft för ibland radikal förändring.

En avgörande social faktor i detta sammanhang är det förhållandet att judar i diasporan alltid utgjort en minoritet. I det avseende skiljer sig judar från de flesta andra invandrare och flyktingar som kommer till ett nytt land, t.ex. Sverige eller Danmark. När man t.ex. i den

11 Walter Benjamin begick självmord genom en överdos morfin sedan hans försök att fly till USA stoppats av gränsvakterna i Portbou på den fransk-spanska gränsen den 25 september 1940.

12 Tes VI i Über den Begriff der Geschichte, publicerad postumt, först i liten upplaga 1942 av det till New York exilerade Institut für Sozialforschung, efter kriget, 1950, för en större publik i Tyskland.

13 Gershom Sholem blev till skillnad från Benjamin sionist, flyttade från Tyskland till dåvarande Palestina och grundlade där den moderna akademiska forskningen om judisk mystik och kabbala. 
danska debatten om integration av de muslimer som kommit dit som invandrare och flyktingar från länder i medelhavsområdet förebrår dem att de inte $-i$ likhet med de judar som i början av 1900-talet fick tillflykt där undan pogromerna i länderna på andra sidan Östersjön - „blir danskar" (Espersen 2009), då bortser man från det väsentliga faktum jag vill peka på här: att judar, var de än levt och vart de än flyttat, alltid sedan templets förstörelse i Jerusalem år 70 enligt vår tideräkning, varit en liten minoritet som levt i diaspora - och därigenom genom två årtusenden utvecklat ett särskild förhållningssätt eller mentalitet som bottnar i vad man skulle kunna kalla ett diasporiskt minoritetsmedvetande. Detta till skillnad från t.ex. de muslimska araber från mellanöstern som på senare år kommit till Danmark, Sverige eller något annat europeiskt land från områden och kulturer där de ingått $i$ en hegemonisk religiös och kulturell majoritet.

När det gäller judarnas historiska erfarenheter är - vid sidan av diasporatillvarons predikament att överallt och ständigt utgöra en religiös/etnisk/kulturell minoritet i det samhälle man lever i - upprepade upplevelser av kulturellt förtryck och livshotande förföljelse en tung del av erfarenhetskapitalet. Inom den judiska kulturen intar minnet en alldeles central plats. Som kanske ingen annan västerländsk kultur vinnlägger man sig i den judiska kulturen om att vårda och hålla minnet av historiska händelser vid liv. Att återberätta, att berätta för sina barn, att levandehålla erfarenheter från generation till genera- tion är både ett religiöst baserat imperativ och ett grundläggande element i den judiska kulturtraditionen. Det gäller såväl mytologiska begivenheter som t.ex. uttåget ur Egypten (Exodushistorien i Bibeln) som faktiska historiska händelser. Således är inkvisitionens förföljelser och utdrivning av judarna från den iberiska halvön under medeltiden, de återkommande pogromerna i Ryssland, Ukraina, de baltiske länderna och Polen under de senaste århundradena, samt de tyska Förintelsefabrikerna i det moderna genombrottets nazistiska Europa levande upplevelser av utsatthet och maktlöshet som på djupet präglar vad jag här kallat »ett judiskt förhållningssätt».

Utöver detta spelar tre faktorer i den judiska kulturen särskilt in för vad jag här kallar ett judiskt förhållningssätt:

Talmud, eller snarare att förhålla sig talmudiskt till livet och verkligheten. Talmud är ett mycket omfattande och särpräglat framställt "diskussionsreferat" spännande över många sekler av tolkningar av och kommentarer till olika bibelavsnitt - samt tolkningar av och kommentarer till dessa, och tolkningar av och kommentarer till dessa, osv. osv. Diskussionerna handlar om allt möjligt som kan dyka upp i människors liv. I Talmud är inget så betydelselöst eller så självklart att det bara kan tas för givet. Talmud anvisar inte en viss tolkning eller uppfattning som mer giltig än någon annan, argument ofta spetsfundiga och intrikat uppbyggda - får ofta stå emot argument utan att en slutgiltig konklusion dras, frågan lämnas öppen för nya tolkningar och argument utifrån de nya förhållanden som kom- 
mentatorn befinner sig i eller kan hänvisa till. ${ }^{14}$

De flesta av dagens judar har säkerligen aldrig studerat talmud. Inte desto mindre har det sätt att ställa frågor, resonera och argumentera som kännetecknar talmud traderats genom generationerna $\mathrm{i}$ den judiska världen och transponerats till att handla inte bara om textavsnitt i bibeln utan om allt möjligt $i$ verkligheten och inte minst i samhället. ${ }^{15}$ Det handlar om att närmast oavbrutet förhålla sig kommenterande och diskuterande till föregivna fakta: - Vad betyder detta? Varför står det/ligger det till på detta viset? och liknande frågor bildar grunden för ett förhållningssätt som i modern skepnad

14 Talmud finns i två versioner: dels den Palestinska Talmud (Yerushalmi), dels den Babyloniska Talmud (Bavli) som är mer än tre gånger så omfattande och har blivit den dominerande i judisk tradition. Den första stora samlingen, den Palestinska Talmud, blev färdig under 300talet f.Kr. Den babyloniska Talmud sammanställdes under en period fram till slutet av 500talet e.Kr. Mer än hälften av den babyloniska Talmud består av berättelser, etiska betraktelser och olika allegorier och är skriven på rabbinsk hebreiska och på arameiska. När man inom den judiska världen talar om att "studera tora", är det för det mesta talmud man åsyftar.

15 Jag har själv vuxit upp i en helt sekulär judisk familj i vilken ingen av mina föräldrar studerat talmud eller var särskilt bevandrad i den judiska textvärlden - men i efterhand har jag förstått att de dagliga livliga samtalen runt middagsbordet och det ständiga argumenterandet om allt möjligt som någon av oss stött på eller undrade över i själva verket var en kulturellt betingad inskolning i vad jag idag skulle beteckna som sekulärt talmudiskt förhållningssätt. har bidragit till att judar som t.ex. journalister, innovatörer, entrepenörer, författare, filosofer, vetenskapare, och kreatörer inom olika discipliner och konstarter bidrar till utveckling, samhällsdebatt och kulturliv (Bredefeldt 2008). ${ }^{16}$

Med detta kommer vi in på den andra faktorn som har sin utgångspunkt att i den judiska föreställningsvärlden ses människan som Guds medskapare. Gud, universums skapare, tänker man sig, skapade världen men han/hon/den/det behöver människan för att fullborda sin skapelse. Den enskilda människan är därför moraliskt förpliktad att genom sina egna handlingar och eget skapande söka förbättra och reparera världen - Tikkun olam är ett begrepp inom judendomen för detta. I likhet med det talmudiska förhållningssättet har också denna princip överlevt sekulariseringen och transponerats in i moderna judars förhållningssätt. Naturligtvis är inte alla judar i egentlig mening skapande inom t.ex. konst, vetenskap eller näringsliv, men inte desto mindre är det en grundsten i ett judiskt förhållningssätt att på olika sätt, om än på blygsam nivå, sträva efter att vara skapande och göra insatser för att förbättra världen.

Judendomen har inga helgon, heller inga

\footnotetext{
16 En klassisk judisk anekdot är denna: den judiske pojken kommer hem från sin första dag i skolan. Pappan frågar honom - Nå, hur var det i skolan? Pojken svarar glad - jag kunde svara på alla lärarens frågor! Pappan svarar misslynt jaja, men kunde du ställa någon fråga som läraren inte kunde svara på?
} 
heliga platser. ${ }^{17}$ "Helighet « - i den utsträckning man överhuvud taget talar om det $i$ judiska sammanhang - tillskrivs utöver Gud varje människa. Ur Mishna, Talmuds äldsta och centrala del kan man utläsa två satser som en människa varje dag kan säga till sig själv: Jag är inget förmer än ett sandkorn och stoft ${ }^{18}$ och Världen skapades för min skull.

På sätt och vis utgör detta ytterligare en grundsten för ett judiskt förhållningssätt. Judendomens religiösa regelverk är primärt inriktat på att helga den mänskliga vardagen och dess återkommande göromål: matberedandet, måltiderna, kärlekslivet, osv. Livet självt, är vad som hålls mest heligt. ${ }^{19}$ För att rädda liv tillåts man i prak-

17 Detta kan tyckas strida mot det ofta hörda uttrycket "Det heliga landet", mot talet om Jerusalem som en "helig stad" för judar (samt kristna och muslimer), eller att "Klagomuren", en kvarvarande ruindel av vad som en gång var Templet i Jerusalem, nu är en "helig plats» för fromma judar. Inte desto mindre innebär det att några, judar som icke-judar, uppfattar saken så - ofta med dramatiska politiska konsekvenser - inte att detta skulle vara förankrat i en judisk idé om vissa konkreta platsers helighet. Däremot kan det vara fråga om ett mer eller mindre medvetet missbruk av religiös terminologi för politiska syften.

18 Jfr. den välkända sats som uttalas vid begravningar: Av stoft är du kommen till stoft skall $\mathrm{du}$ åter varda. I Bibelns skapelseberättelse var Paradisets Adam bara stoft intill Gud med sin ande blåste liv i honom.

19 Det hebreiska ordet för "Skål!" är l'chaim som betyder "till livet". tiken bryta alla andra religiösa bud. ${ }^{20}$ En mycket stor del av de judiska buden - den hebreiska bibeln rymmer enligt rabbinska tolkningar 613 bud (mitzvot) som anger vad man som observant jude skall, respektive inte får göra ${ }^{21}$ - syftar till att reglera det vardagliga livet, i synnerhet samvaron mellan människor. I judendomen är det människans vandel och samvaro med sina medmänniskor i familj, vardagsliv och samhälle som står i centrum. De eskatologiska frågorna, frågan om livet efter detta, himmelrike och helvete, ägnar judendomen endast förströdd uppmärksamhet. Livet här på jorden med och bland människorna är vad som framför allt sätts i fokus i den judiska traditionen.

20 Regeln kallas på hebreiska pikuach nefesh och innebär t.ex. att den som håller på att förgås av svält t.ex. i ett koncentrationsläger för att rädda sitt liv kan äta svinkött som annars inte är tillåten föda (kosher) för en jude, eller att man om det är nödvändigt för att försvara sig mot livshotande angrepp, tillåts bära t.ex. vapen på sabbaten (då man annars enligt halacha inte bör bära något alls).

21248 av dessa mitzvot är positivt formulerade och anger handlingar som man som jude är förpliktigad till, t.ex. att tända sabbatsljusen och 365 är negativt formulerade och anger handlingar som man förbjuds att göra, t.ex. äta fläsk. Sju av de 613 buden utgör tillsammans de s.k. Noaitiska buden och gäller inte bara för judar utan för alla människor. Bland dem är t.ex. buden att inte döda, inte stjäla, att döma folk enligt lag av domstolar, m.m. Efter Förintelsen har den judiske filosofen Emil Fackenheim formulerat vad han kallar den 614:e mitzvan: Att efter Förintelsen självmant ge upp sin judiska tillhörighet vore att ge Hitler en postum seger. Att göra det skall vara moraliskt förbjudet för varje jude!(Fackenheim 1994 s. 213). 
Inom varje trosriktning, religiös, ideell eller politisk, utvecklas ortodoxier och grupperingar som anser sig förvalta och försvara den "sannau läran. Så också inom judendomen. Ofta ser omvärlden just dessa de mest extrema och utrerade företrädarna som de mest nautentiska" företrädarna för den kulturföreteelse eller åsiktsriktning det är fråga om. Den outtalade premissen är att de reformerade, moderna osv. varianterna av t.ex. judiskt liv bara är urvattnade former av religionens eller ideologins "kärna"; att de som lever så endast gör det av bekvämlighetsgrunder och i själva verket endast är bleka, eller i värsta fall t o $\mathrm{m}$ falska företrädare för den "egentliga läran" (judendomen, socialismen, islam, kristendomen eller vad det nu gäller). Men åtminstone när det gäller judendom är detta en helt inadekvat ståndpunkt. Judendomen har en grundtext den hebreiska bibeln - men den talar så att säga aldrig direkt till människan. Det som står där måste och skall enligt den judiska traditionen hela tiden tolkas utifrån den situation man aktuellt och faktiskt befinner sig i. Någon judisk teologi, i stil med den kristna, finns inte. Gud är - punkt. För den judiske 1600-tals filosofen Baruch Spinoza $^{22}$ har Gud en gång för alla genom uppenbarelsen på Sions berg via Moses givit mänskligheten sin lära, Toran - av

22 Som en av de få i den judiska historien blev Spinoza, som verkade i det dåvarande spanska Nederländerna (nu Holland), för sina kätterska synpunkter bannlyst ur den judiska församlingen. kristna kallad "Gamla testamentet«. ${ }^{23} \mathrm{Vad}$ därutöver skall gälla är det människans uppgift att finna fram till.

I den judiska världen finns det inte någon hierarki av biskopar, ärkebiskopar, kardinaler och påvar som har privilegium på att utlägga vad som är Guds vilja och mening. Heller inga gestalter som skulle vara Guds särskilda sändebud. Religiösa funktionärer och torakunniga personer (i äldre texter ibland kallade "skriftlärde») kan förkunna olika uppfattningar. Men judendomen lämnar åt var och en att själv genom eget studium av tora och i fortlöpande diskussion med de många och ofta motstridiga kommentarer till hur det som sägs där skall tolkas, som talmud innehåller, finna fram till vad som skall gälla för honom eller henne.

I den judiska traditionen är ordet och texten en auktoritet, men en alltid omstridd auktoritet. I ordet och texterna,

23 En beteckning som inte accepteras inom judendomen eftersom den inte erkänner "Nya testamentet» som en helig skrift. Rent språkligt skulle man f. ö. lika gärna kunna kalla „Gamla testamentet" för det "primära" och Nya testamentet för det "sekundära" testamentet - men de värderingsmässiga konnotationerna skulle därmed givetvis förskjutas. Vid uppenbarelsen på Sinai berg överlämnade Gud enligt legenden till Moses (och därmed mänskligheten) sin lära dels i skriven form, det är den som utgör "Gamla Testamentet", dels i en lika viktig men icke nedskriven form, kallad "den muntliga toran". När man inte använder den hebreiska beteckningen Tanach för bibeltexten använder judiska företrädare företrädesvis benämningen "den hebreiska bibeln". 
ja för några i själva bokstäverna ${ }^{24}$, antas insikter finnas förborgade, insikter som dock inte utan vidare framträder, utan som alltid måste tolkas fram och relateras till den situation man befinner sig i. På det sättet leder den för judendomen centrala och bärande texttolkningstraditionen ${ }^{25}$ såväl till ett för många förvånande frimodigt och icke-auktoritärt gudsförhållande som till en pluralism av tolkningstraditioner existerande sida vid sida samt - det är särskilt väsentligt i detta sammanhang - en flexibilitet som möjliggör förändring av sedvänjor och förhållningssätt över tid och skiftande förhållanden. Man kan så att säga alltid vara moderna utan att vara traditionslösa. Och man kan - och är ofta oeniga utan att för den skull vara ovänner. Inom den judiska världen används begreppet Einheitsgemeinde för att beteckna en judisk församling, som t.ex. den i Stockholm, som inom sig rymmer flera olika religiösa riktningar ${ }^{26}$, var och en med deras gudstjänster, osv.

24 Inom kabbala, den judiska mystiken, och delar av Talmud tillskrivs varje bokstav i det judiska alfabetet särskilda numeriska, mystiska och heliga egenskaper.

25 Se kapitlet »The power of the Text« i litteraturprofessorn vid UCLA, Berkeley, Robert Alters bok Necessary Angels. Tradition and Modernity in Kafka, Benjamin and Sholem, 1991.

26 Stora synagogan i Stockholm hör således till den s.k. masorti-rörelsen, en modernt inriktad icke-ortodox judendom, men inom församlingen finns också två mindre ortodoxa synagogor och en s.k. progressiv judisk grupp som har en mer liberal tolkning av judendomens levnadsregler än de övriga religiösa grupperingarna inom Stockholms judiska Einheitsgemeinde (enhetsförsamling).
I den första volymen, Authority, av samlingsverket The Jewish Political Tradition, sammanställt av den amerikanske samhällsanalytikern och filosofen Michael Walzer (2000) diskuteras hur man inom judisk tradition ser på kontroverser och avvikande meningar. En minoritets synpunkter skall allid nedtecknas och bemötas med samma respekt som en (för tillfället) vinnande majoritets - hela historien om kampen mellan olika tolkningar i Talmud kan sägas illustrera just det. Talmud (traktaten Sanhedrin) och den judiska traditionen rymmer en doktrin om den upproriske vise ("the rebellious elderu). Det är en som efter ett avgörande i Sanhedrin, den högsta domstolen, i sin lokala församling följer en annan linje än den som majoriteten eller högsta domstolen formulerat. Den upproriske vise tillerkänns friheten att uttrycka sin avvikande mening, också att undervisa sina studenter om den, men får inte upphöja den till lag (dvs. skapa en konkurrerande Tora).

Talmud talar tydligt på denna punkt: inte ens om man måste underkasta sig lagen får en människas intellektuella frihet kränkas. Det finns t o m en än mer radikal tolkning av denna judiska tradition som går ut på att uppror ibland kan vara moraliskt påbjudet: om någon av en församlings vise inte följer sin övertygelse utan bara underkastar sig den konventionellt rådande ordningen, är själva lydnaden ett moraliskt brott. Särskilt aktuellt blir detta i den judiska diasporan. I traktaten Yevamot 14 i den babylonska talmud klargörs först hur församlingar i olika städer kan - och har rätt att - anta olika regler och tolkningar allt efter omständigheterna, men därefter också hur man även inom en och samma 
stad (församling) kan ha olika regler och tolkningar utan att någon av dem därför behöver betecknas som "upprorisk».

Man utgår ifrån och verkar inom en och samma tradition; man läser och kommenterar samma kommentarer, man är oenig om tolkningen av en och samma text. Och det är helt OK.

Alltså: på en och samma gång å ena sidan tolkningsfrihet och bejakande av det positiva i den pluralism det leder till, och å andra sidan bevarad enhet inom denna ram. En skärpt student, ansåg de vise, skulle kunna ge 49 goda argument för en bestämd tolkning, men också 49 argument mot samma tolkning - inom judisk tradition ses detta inte som sofisteri, tvärtom: Bibelns ord, så ser talmud på det, är hela tiden öppna för nya tolkningar, och för diskussioner som innebär att man inte är överens, men också överens om att man inte behöver vara det. Också detta är ett grundelement i vad jag här benämner »ett judiskt förhållningssätt».

I det följande skall vi undersöka hur detta tillsammans med de övriga element jag beskrivit som grundläggande för nett judiskt förhållningssätt» kan förklara den särskilda relation till makt, utsatthet, integration och överlevnad som den judiska gruppen utvecklat i de moderna västerländska samhällena.

Som inledning till det skall vi något mer konkret bekanta oss med den judiska gruppen i dagens Sverige.

\section{Dagens judiska scen i Sverige}

Hur man skall "räkna judar« är en ytterst grannlaga fråga. Beroende på vilka kri- terier som användes kommer utfallet att variera mycket. Det är dock klart, oavsett vilket kriterium som används, att endast en relativt liten andel av judarna i Sverige har registrerat sig som medlemmar i en av landets tre judiska församlingar. Sådana finns i Stockholm, Göteborg och Malmö. ${ }^{27}$ Det rör sig om tillsammans knappt 7000 individer som genom sina medlemsavgifter betalar för församlingarnas aktiviteter. För gemensamma angelägenheter har man 1953 bildat paraplyorganisationen Judiska Centralrådet $i$ Sverige. Stockholms judiska församling är medlemsmässigt mer än dubbelt så stor som de två övriga församlingarna tillsammans. Alla tre församlingar är vad som i europeisk judisk tradition kallas en Einheitsgemeinde, det vill säga öppen för medlemskap för alla judar ${ }^{28}$ enligt det kriterium som tillämpas för varje församling. Demografiska uppskattningar ${ }^{29}$ anger att högst hälften av de judar i Sverige som uppfyller de strikta kriterier för medlemskap

27 Utöver detta finns mindre judiska föreningar i Uppsala, Norrköping, Borås, Helsingborg, Västerås, Eskilstuna, Lund, Varberg och Härnösand.

28 Enligt halacha, den judiska lag som ortodoxa rabbiner har som rättesnöre, är den jude som är född av judisk mor eller som har konverterat till judendom efter prövning hos en erkänd ortodox rabbin. Judiska församlingen i Stockholm godkänner också medlemskap för en person som har en judisk far, men inte en judisk mor. Medlemskriterierna varierar något mellan församlingarna.

29 Av professorn i judisk demografi Sergio della Pergola vid Institute of Contemporary Jewry, Hebreiska Universitet i Jerusalem (DellaPergola 1999). 
som ortodoxa församlingar använder sig $\mathrm{av}^{30}$ har valt att ansluta sig till någon församling. Minst lika många av dem som är judar enligt ett sådant kriterium är inte medlemmar i någon judisk församling. Till detta kommer åtskilliga fler som genom härkomst, släktskap och familjebildning har någon bindning till judiskt liv och erfarenhet. Antalet medborgare i Sverige som med detta vida kriterium kan anses berörda av "det judiska" kan uppskattas till ca tjugofaldigt så många som medlemsantalet i de judiska församlingarna. Med andra ord har kanske uppemot 150000 människor i Sverige någon slags judisk kulturell anknytning - varav de flesta dock knappast skulle beteckna sig själv som »jude». För att betraktas som jude eller judinna krävs, förutom att personen $\mathrm{i}$ fråga har något slags konkret och någorlunda nära personlig anknytning till det judiska folket och den judiska traditionen ${ }^{31}$, att personen själv vill beskriva sig som sådan. Uppskattningsvis är antalet judar i denna mening något färre än 20000 i dagens Sverige - det är dessa som utgör vad jag vill beteckna som den judiska befolkningen i Sverige.

I motsats till vad som gäller för andra länder i Europa ${ }^{32}$, där den judiska befolkningen genom Förintelsen blivit betydligt decimerad, lever det idag fler judar i landet

30 Se fotnot 28.

31 För ortodoxa judar är den enda giltiga anknytningen att man är född av en judisk mor eller har konverterat till judendom hos en ortodox rabbin.

32 Frankrike och Spanien utgör möjligtvis undantag. än vad det någonsin har gjort. ${ }^{33}$ De flesta av dem är välutbildade, sekulärt orienterade och klart judiskt identifierade. Snarare än ett religiöst engagemang är det ett historiskt betingat kulturellt engagemang för "det judiskau som är det judiska livets bas i dagens Sverige. Den förlamning som emanerat från Förintelsen har hos den nu aktiva generationen judar börjat släppa sitt grepp om sinnena samtidigt som diasporajudenheten, också den i Sverige, alltmer bejakar sin kulturella egenart och självständighet i förhållande till den koppling till staten Israel som för många judar, i de första årtiondena av denna stats existens, var självklar.

I den undersökning som under min ledning genomfördes åren efter millennieskiftet $^{34}$ av den grupp judar i Sverige som valt att registrera sig som medlemmar i någon av de tre judiska församlingarna, framkom att i stort sett alla i denna grupp upplever sin judiska identitet mycket starkt, samt att detta för de flesta av dem framför allt bottnar i en känsla av att tillhöra det judiska folket och ha del i det judiska kulturarvet. Det etniskt-kulturella inslaget i de judiska församlingsmedlemmarnas upplevelse av sin judiska identitet är markant.

På frågan »Hur viktig är var och en av följande aspekter för din känsla av' judiskhet'? svarar de flesta att det som upplevs som viktigast är »känslan av att var jude innerst

33 Vid nazisternas Machtübernahme i Tyskland var antalet judar i Sverige ca 7000.

34 Lars Dencik \& Karl Marosi: Judiskt liv i Sverige - identitet, levnadsvanor och attityder bland medlemmarna $i$ de judiska församlingarna $i$ Sverige vid ingången till 2000-talet, Judiska Centralrådet i Sverige, 2007. 
inne (t.ex. i personlighet, tänkande, etc.)", "lojalitet med mitt judiska arv« och »samhörighet med andra judar».

Något som kan liknas vid en judisk kulturell pånyttfödelse har de senaste årtiondena svept genom stora delar av västvärlden. Det handlar dels om nyskapande och modernistiskt inriktade kulturproduktioner som på olika sätt gestaltar judiska erfarenheter och perspektiv dels om revitalisering av traditionella kulturyttringar såsom t.ex. den judiska klezmermusiken, som blivit populär långt utanför judiska kretsar. Över hela Europa har det byggts nya judiska museer som inte bara kommit att fungera som förmedlare av kunskap om judendom och den judiska historien utan också i sig själva, som t.ex. Judiska Museet i Berlin, är manifestationer av modernt judiskt skapande. I Sverige finns idag också ett aktivt judiskt museum, liksom ett judiskt bibliotek, en judisk filmfestival, en judisk teater, ett judiskt förlag, en judisk kulturtidskrift (Judisk Krönika), osv. Samtliga dessa institutioner vänder sig med sina aktiviteter och arrangemang inte bara till den judiska gruppen i Sverige utan ut till hela den svenska allmänheten. ${ }^{35}$

Den judiska gruppen i Sverige uppfyller

35 Det skall i detta sammanhang påpekas att på grund av den judiska gruppens utsatthet för antisemitiska angrepp och andra politiskt färgade hot, även i dagens Sverige, kräver kulturevenemang i judisk regi eller med tydligt judiskt innehåll ofta särskilda säkerhetsåtgärder för att kunna genomföras med någorlunda trygghet för medverkande och besökande. Detta, tillsammans med de senaste årens häftiga Israelkritik, har bidragit till att den revitaliseringsvåg som bröt fram på 1990-talet under de senaste åren har mattats betydligt. de kriterier man brukar anlita när man vill definiera något som ett fungerande civilsamhälle. Man har etablerat ett litet, relativt autonomt och på frivillighet byggt samhälle i samhället. Man har parlamentariskt vald styrande församling, man organiserar och sköter social omsorg för gruppens medlemmar, man driver daghem, skola och fortbildningsverksamhet, man sörjer för gruppens religiösa, rituella och andliga behov och man har många specialiserade föreningar t.ex. för ungdom, kvinnor, sport samt institutioner och driver en omfattande kulturell verksamhet vänd till den egna gruppen liksom till den breda allmänheten.

De initiativ och verksamheter inom judiskt kulturliv som de senaste årtiondena iscensatts i Sverige och som gått ut på att judiska kulturyttringar och judiska perspektiv inte utan viss stolt självmedvetenhet presenterats också utanför de redan införståddas krets, och för en icke-judisk allmänhet, har inneburit en brytning med en traditionell judisk hållning att hålla sig "innanför murarna" och att »ligga lågt" i förhållande till det omgivande samhället.

En del av förklaringen till detta ligger i det genombrott för en pluralistisk kultursyn som följt av att Sverige som land blivit allt mer mångkulturellt.

\section{Från mosaiskt majoritets- kramande till judiskt minoritetsmedvetande ${ }^{36}$}

Idag är den judiska gruppen i Sverige en

36 Detta avsnitt bygger på mitt bidrag till Judisk

Krönikas Jubileumsnummer när tidskriften fyllde 75 år (Dencik 2007b). 
av Sveriges fem officiellt erkända "nationella minoriteteru. Vägen dit beskriver en intressant utvecklingslinje återspeglad i bl.a. den judiska kulturtidskriften Judisk Krönikas egen historia. Tidsskriften JUDISK (med versaler) Krönika grundades för något över sjuttiofem år sedan, då de nuvarande judiska församlingarna i Sverige fortfarande betecknade sig som Mosaiska församlingar. Namnet innebar mycket mer än bara att markera att man hade en annan religion än majoritetssamhällets kristna. Då, 1932, levde det inte mer än ca 7000 judar i hela landet. Varav alla var tvungna att vara registrerade medlemmar i ett mosaiskt trossamfund såvida de inte konverterat till kristendomen och blivit medlemmar i den svenska statskyrkan (som inte avskaffades förrän vid millennieskiftet och som man som "vanlig svensk" föddes in i). Ända till 1952 var man nämligen som svensk tvungen att vara medlem i något officiellt erkänt trossamfund i Sverige - alltså antingen en mosaisk eller en kristen församling. Den svenska statskyrkan hade sin Kristus, det var därför de betecknade sig som just "kristna". Hur skulle judar vars tongivande delar vid den tiden (och ett gott stycke både dessförinnan och därefter) till varje pris strävade efter att inte bli sedda som »judar", dvs. uppfattade som en från majoritetssamhället avvikande och särpräglad folkgrupp i samhället (som man ju ändå blev) kunna matcha det? Ja, en Kristus hade man inte, men en Moses alltså betecknade man sig i analogi med de "kristna» som "mosaisk".

Att i det läget framhäva, som redan namnet på den då nystartade tidskrif- ten gjorde, att man var judisk innebar att bejaka den kulturella och etniska särprägeln hos sig själva. Något som både tongivande kretsar i de egna leden och välmenande och - skulle vi idag säga, "politisk korrekta« medmänniskor ur majoritetssamhället - inte ville veta av.

I ett av Judisk Krönikas första nummer utgivet i maj 1933 (alltså alldeles efter Hitlers Machtübernahme i Tyskland) noterar Elieser Berlinger under rubriken "Nation eller konfession?" att „Frågan om den judiska gemenskapens väsen hör till de mest omdiskuterade problemen $i$ vår tid». Och han konstaterar vidare: „Först då upplysningstiden så småningom även hade till följd judendomens emancipation i olika länder, började den judiska problemställningen ta fast gestalt. För vilket pris skulle judarna i olika länder köpa sig en människovärdig tillvaro?"

Han besvarar sin egen fråga:

"Det var väl ett av de största självbedrägerierna $i$ världshistorien, som hände den gången, då ansenliga judiska skikt ville borteliminera det judiska folkbegreppet och borttrolla vår nationella existens ur det realas värld, då man försökte att av det judiska livsinnehållets mångfald bilda det ytliga begreppet judisk konfession. "

1936 skriver signaturen "Mako» i Judisk Krönika:

"Härstamningen från en annan folkstam har ingenting att göra med patriotism och medborgarskap. Eljest skulle exempelvis ej heller en lapp vara en god svensk medborgare...[--]...vi judar måste emellertid vara 
på det klara med att vi $i$ ingen stat $i$ världen tillhöra den folkstam, som bildar majoriteten inom vederbörande land. Judarna $i$ Frankrike är inga galler, judarna $i$ England inga anglosachsare och judarna $i$ Sverige inga vikingar, även om de gärna skulle vilja vara det."

Den sista bisatsen, påpekandet att svenska judar nog gärna skulle vilja vara vikingar, var inte långsökt. Året var 1936. Frestelsen att krypa undan med sin judiskhet på grund av vad man då redan visste om nazismens anti-judiska politik i Tyskland var stor och djupt förståelig. Men, som vi nu vet, lönlös.

Frågan om "dubbla lojaliteter" har ofta dykt upp i samband med vad som i dessa debatter kommit att kallas "judefrågan". Också i judiska kretsar och i Judisk Krönika. Även efter de förödande krigs- och förintelseåren. I en artikel från den omedelbara efterkrigstiden $(\mathrm{Nr} 7,1950)$ tar Ernst Benedikt upp frågan, och vänder sig med en rad historiska jämförelser som argument mot påståendet, att judar genom att bejaka sin nationella särart skulle hamna i vad han kallar »den så kallade dubbla lojalitetens problem». I det ligger bl.a. föreställningen - återigen aktualiserad i de kritiska röster som höjs mot multikulturalismen idag - att sammanhållningen i ett samhälle hotas av att medborgarna i samhället hör till olika etniska grupperingar.

I efterdyningarna av katastrofen för judenheten i Europa, en judenhet som inte minst i Tyskland (i många avseenden modell också för den svenska judenheten) - fram till dess gått långt på självutplåningens och assimilationens väg, började ett nytt judiskt självmedvetande att ta gestalt.
Efter det som hänt judarna i Europa, skall den judiska gruppen i det demokratiska Sverige, skrev man för 60 år sedan i Judisk Krönika, inte längre låta sig spisas av med "uppvärmd korv från hatets eld".

Från denna utgångspunkt har det utvecklats en linje som nu blivit grundfäst i det judiska Sverige - att judar inte bara, eller ens i första hand, bör betraktas som en religiös gruppering bland andra, men att den judiska gruppen i Sverige utgör en etnisk (kulturell/nationell) minoritet med rätt till inte bara att få utöva sin religion (för dem som önskar det), men med rätt också till ett civilt liv centrerat runt sin egen etniska och kulturella identitet.

Med detta nåddes en avgörande vändpunkt för europeiskt judiskt självmedvetande. Varken den från förmodern tid kvarlevande ghettojudendomen (både påtvungen och självpåtagen), eller den moderna assimilationsjudendomen hade visat sig vara någon väg till överlevnad. Alldeles tvärtom. Hur skulle man då gå vidare?

Vändpunkten har med genombrottet för upplysningsfilosofins emancipationstanke och det demokratiska systemets konsolidering i Europa att göra. Som det stod i Judisk Krönika redan år 1933: „Först då upplysningstiden så småningom även hade till följd judendomens emancipation i olika länder, började den judiska problemställningen ta fast gestalt». Att bli betraktad som och erkänna sig själv som minoritet har helt olika innebörd och potentiella konsekvenser i olika faser av europeisk historia. I fördemokratiska och pre-emancipatoriska samhällen innebär det att ha minoritetsstatus att leva på makthavares nåd och vara utsatt för deras och majoritetsbe- 
folkningens godtycke. Det vet alla judar pogromerna i Ryssland har lämnat levande avtryck i judisk medvetenhet. Att acceptera en minoritetsställning vore att välja utsatthet - i stället eftersträvade man, inte sällan draperad i socialismens röda fanor, jämställdhet, fullvärdigt medborgarskap, likhet. Också, förståligt nog, om det måste innebära ett visst mått av kulturellt självförnekande.

Men när jämställdhet, fullvärdigt medborgarskap, och likhet inför lag och myndigheter är uppnådd, alltså under postemancipatoriska samhällsförhållanden, ja då ändras ekvationen. Då innebär det att acceptera sin kulturella (eller »etniska» eller "nationella" - språkbruket varierar, men de olika begreppen refererar till samma sakförhållande) särart, och göra anspråk på att den respekteras på samma sätt som andra särarter i samhället, tvärtom att ta ytterligare ett, men ett kvalitativt annorlunda, steg mot faktisk jämställdhet. Det är det som skett i och med att judar erkänts som och nu själva ser sig som en nationell minoritet i dagens Sverige.

\section{Exkurs: Assimilation eller integration?}

Begreppen assimilation och integration hör till de flitigast använda och ofta medvetet missbrukade i debatten om invandrare och minoriteter. Därför några korta klarläggande definitioner:

Med assimilation menas att individer upptas i en existerande social gemenskap genom att i socialt signifikanta avseenden bli likadana som de andra i gemenska- pen. Två olika assimilationsprocesser kan särskiljas: en "osmotisk" eller automatisk assimilation, som innebär att individen successivt och utan påtagliga sociala friktioner sugs upp i och blir likadan som det omgivande samhällets övriga medlemmar, och en påbjuden eller forcerad assimilation, som innebär att individen genom olika former av medveten påverkan från sociala makthavares sida - t.ex. genom fostran, skolning eller t o $\mathrm{m}$ våld eller hot om våld - fås att uppföra sig så som är normerat av samhällets makthavare.

I Sverige är det idag få förutom Sverigedemokraterna som öppet förordar assimilation. Men samtidigt har den under lång tid förda politiken gentemot invandrare och etniska minoriteter de facto mest varit inriktad på att med olika medel försöka få de "främmande» i landet så assimilerade som möjligt i den nationella majoritetskulturen.

I den politiska retoriken kallar man ofta rena assimilationsåtgärder för integrationspolitik. Men integration är något annat än assimilation. Integration innebär den sociala process genom vilken en person kommer att ingå i en sammanhängande social helhet som en likvärdig part, samtidigt som personens egen personliga och kulturella integritet bevaras.

En integrationspolitik består således av två sammanhängande delar; dels att verka för att skapa eller bibehålla en sammanhängande, "integrerad" social helhet samtidigt som nya medlemmar tas upp i den samtidigt som man respekterar och bevarar de involverade personernas och etniska gruppernas personliga och kulturella integritet.

När individer varken lyckas assimileras eller tillåts bli integrerade i samhället inne- 
bär detta att dessa människor marginaliseras. Det rör sig om individer med etnisk minoritets- eller invandrarbakgrund som just på grund av sin strävan att assimilera sig till majoritetssamhällets normer och livsstil tappat sin förankring i den egna gruppen. I vissa fall kan deras "nya» beteenden och förhållningssätt innebära en så stark distansering från ursprungsmiljön att de blir mer eller mindre utstötta också ur denna. Samtidigt blir de, på grund av sitt fortfarande märkbara främlingskap, inte heller accepterade som likvärdiga av majoritetssamhället. Individerna försätter sig således i en situation där de samtidigt både ställs utanför den egna ursprungskulturen och hålls utanför majoritetskulturens gemenskap och blir därmed dubbelt marginaliserade. Detta är just vad som håller på att inträffa för stora grupper av invandrare i t.ex. dagens Danmark - med förödande konsekvenser både för dem det drabbar som hamnar i ett normativt limbo (där gängbildningar som utvecklar egna, ofta hårda spelregler vid sidan om gällande lagar och moralregler frodas och tar sig uttryck i våld och kriminalitet, inte sällan legitimerad av eller uppblandad med politisk och/ eller religiös fanatism) - och för majoritetssamhället som får leva med dessa "outlaws" mitt ibland sig och det hot mot allmän säkerhet dessa utgör. I Danmark har den under det senaste årtiondet förda politiken lett till att relativt stora grupper av invandrare och flyktingar har hamnat i en sådan dubbelmarginalisering.

Mot detta kan ställas de resultat som en svensk doktorsavhandling (Sterner Carlberg1994) som undersökt judiska barns integration i det svenska samhället påvisat. Här pekar författaren Mirjam Sterner Carlberg på hur en rakt motsatt mekanism, som hon kallar "dubbel-integration", varit den mekanism som fört till en för denna judiska grupp lyckosam integration i det svenska samhället.

Genom att de judiska barnen, i detta fall huvudsakligen barn till överlevande från Förintelsen, fått en god förankring i den egna kulturen samtidigt som de betraktats som fullvärdiga medlemmar i majoritetssamhället har grunden lagts för ett förhållningssätt som tjänat både gruppmedlemmarna själva och samhället i stort. En känsla av bevarad integritet har kunnat utvecklas vid sidan av en upplevelse av acceptans och integration i det svenska samhället. Den judiska gruppens sätt att bevara och odla sin egen kulturella särart har inte bara varit ett sine qua non för gruppens egen kulturella överlevnad, det har samtidigt tjänat som en väsentligt bidragande faktor för den judiska gruppens stort sett mycket goda integration i det svenska samhället. Bredefeldt (2008) når i sin undersökning av ekonomi, identitet och assimilering bland judar i Stockholm och Norden under årtiondena runt förra sekelskiftet till resultat som också stöder detta - "de nordiska judarna var olika men ändå lika» (s. 200).

\section{Judar och icke-judar}

Hur uppfattar då judar i Sverige sig själva i förhållande till den svenska majoritetsbefolkningen?

I vilken grad präglas deras sociala liv av att de är judar? Hur relaterar de sig till »de andra", dvs. de icke-judiska medmänniskor de lever samman med i det svenska samhället? I 
den frågeformulärsundersökning som i början av 2000-talet riktades till medlemmarna i de tre judiska församlingarna i Sverige ställde vi följande frågor för att få detta belyst: ${ }^{37}$

Skulle du i princip kunna tänka dig att vara gift med en icke-jude?

Hur förhåller du dig till påståendet "En jude bör gifta sig med någon som också är jude»?

Hur förhåller du dig till påståendet „Om jag hade en son som skulle vilja gifta sig med en icke-jude skulle jag göra allt vad jag kunde för att försöka förhindra det»?

Hur förhåller du dig till påståendet »Om jag hade en dotter som skulle vilja gifta sig med en icke-jude skulle jag göra allt vad jag kunde för att försök a förhindra det»?

Hur förhailler du dig till påståendet "Assimilation utgör en större fara för judenheten än antisemitismu?

37 I samförstånd med Judiska Centralrådet i Sverige och Institute for Jewish Policy Research i London, som koordinerat andra undersökningar med liknande inriktning, och i samarbete med dåvarande ordföranden för Judiska Församlingen i Göteborg professor Sigvard Rubenowitz utarbetade sociologen Karl Marosi och jag frågeformuläret Frågor om judiskt liv som underlag för den undersökning vi åren runt 2000-talet genomfört med medlemmarna i de tre judiska församlingarna i Sverige. Frågeformuläret omfattar knappt hundra frågor varav flera med många delfrågor om hur man upplever sig själv som jude, om vilka levnadssvanor och erfarenheter man har, och om ens inställning både till specifikt judiska förhållanden och till mer allmänna livs- och samhällsfrågor (se Dencik \& Marosi 2007).
När det är jul - har ni då något som har med julen att göra i ert hem?
a. Julklappar?
b. Julmat?
c. Julpynt?
d. Adventskalender?
e. Julgran?
f. Adventsljus?

Upplever du att det finns attityder, värderingar och personlighetsdrag som är vanligare bland judar än bland andra? Vad anser du är vanligast bland judar och vad är vanligast bland andra?

a. Ta omsorg om de gamla

b. Självmedvetenhet

c. Paranoia (förföljelsetankar)

d. Intelligens

e. Materialism

f. Tolerans och respekt för andra

g. Prålighet

h. Sparsamhet

i. Vara politiskt vänsterorienterad

Ibland hör man att judar skiljer sig frän resten av befolkningen $i$ vissa avseenden. Vad skiljer enligt din uppfattning den judiska befolkningsgruppen från den övriga befolkningen?

a. Stark samhörighetskänsla

b. Djup religiös övertygelse

c. Respekt för lag och ordning

d. Stöd för kvinnans rättigheter

e. Rasfördomar

f. Tvivelaktig affärsetik

g. Omsorg om miljön

h. Skilsmässor

Anser du att judar, just för att de är judar, $i$ särskild gradbör... 
a)... lämna bidrag till välgörande ändamål?

b)... hjälpa folk som diskrimineras?

Hur förhåller du dig till påståendet "I kritiska situationer kan judar bara lita på andrajudar»?

Hur ofta finner $d u$ att rapporteringen $i$ massmedia är snedvriden eller orättvis när det gäller judar i allmänhet?

Upplever du att rasismen har ökat, minskat eller är ungefär oförändrad $i$ Sverige under de senaste fem åren?

Om vi ser speciellt på antisemitismen - upplever du att den har ökat, minskat eller är oförändrad?

Har du personligen varit utsatt för antisemitism här i Sverige under de senaste fem åren?

Har du någonsin tidigare (än de senaste fem åren) personligen varit utsatt för antisemitism här i Sverige?

Hur förhåller du dig till påståendet "Vissa judars uppförande kan väcka antisemitism «? 38

38 Frågan om vissa judars uppförande kan bidra till att väcka antisemitism ansågs av Göteborgsförsamlingen som så provocerande att de inte ville ta med den i undersökningen där. Men frågan kunde ställas till medlemmarna i de två andra församlingarna. Det visar sig intressant nog att två tredjedelar av medlemmarna både Stockholm och i Malmö instämmer i påståendet.
De exakta svarsfördelningarna på dessa frågor återfinns i Dencik och Marosi (2007). Generellt sett visar svaren att medlemmarna i de judiska församlingarna i Sverige har en öppen attityd till sin icke-judiska omvärld, även om antisemitism är något som många medlemmar personligen har upplevt i Sverige. Och även om man anser assimilation vara ett hot, tillägnar man sig i viss omfattning klart icke-judiska sedvänjor som t.ex. julfirande. När det gäller de flesta personliga och mänskliga egenskaper upplever man inte att det är någon påtaglig skillnad mellan "de andra" och judar - men att judar ändå på något sätt är mer av vad det nu är fråga om och har ett särskilt ansvar, just för att man är jude.

Betydligt fler svarar Ja än Nej på frågan om de i princip kunde tänka sig att vara gift med en icke-jude. Även om fler än hälften av respondenterna kan tänka sig att vara gift med en icke-jude, anser en nästan lika stor andel att det är önskvärt att en jude gifter sig med en annan jude. Normen att en jude bör gifta sig med en jude framstår således som en idealföreställning, men en som man förhåller sig tämligen pragmatiskt till. Detta understryks av medlemmarnas ställningstagande till hur de skulle förhålla sig om deras egna barn skulle vilja gifta sig med en icke-judisk partner. En av fyra skulle visserligen försöka att förhindra det, medan en dubbelt så stor andel tvärtom tar avstånd från att 
gripa in i den unges val av livspartner. ${ }^{39}$

Men även om man som judisk förälder i det moderna Sverige går in för att det är den unges rätt att själv välja livspartner och livsbana anser nästan hälften av alla medlemmar att assimilation utgör en större fara än t o m antisemitism. Det visar sig också att de som lever samman med en icke-judisk partner - det gäller för ungefär $1 / 3$ av medlemmarna i de svenska judiska församlingarna - och alldeles särskilt de som har barn tillsammans med en icke-jude, i stor utsträckning har anammat en icke-judisk sedvänja som t.ex. att fira jul. Julklappar delar man ut i knappt 20 procent av de familjer där båda parter är judar, men i drygt 70 procent av de familjer där endast den ene parten är jude. Julgran och adventskalender har några få av de familjer där båda är judar, men runt 40 procent av de familjer där endast en part är jude. Analogt förhåller det sig med sådant som julmat, julpynt och tändandet av adventsljus.

När det gäller frågan om det finns skillnader $\mathrm{i}$ värderingar och personlighet mellan judar och andra visar det sig att på åtta av nio specificerade områden menar de flesta att det inteär någon skillnad. Det gäller spar-

39 Om barnet är ens dotter eller ens son spelar ingen som helst roll för föräldrarnas ställningstagande. Anledningen till att det frågas separat om söner och döttrar är att det kan ha betydelse för om barnbarnen kommer att räknas som judar. Enligt Halacha (traditionell judisk lag) är den jude som är född av en judisk mor, men inte den som »bara» har en judisk far. För vissa föräldrar kunde det därför tänkas vara mer angeläget att förhindra sina söner från att gifta sig icke-judiskt, eftersom barnbarnen då inte automatiskt skulle räknas som judar. samhet, prålighet, tolerans och respekt för andra, materialism, att vara vänsterorienterad, intelligens, paranoia och självmedvetenhet. Men en betydande andel, mellan 25 och 40 procent av medlemmarna i de judiska församlingarna i Sverige anger att med undantag för det att vara politiskt vänsterorienterad, är de här nämnda egenskaperna mer utmärkande för judar än för andra. Mest markant anser de judiska respondenterna att de skiljer sig från andra när det gäller att ta omsorg om de gamla - det anser två tredjedelar av medlemmarna är vanligare bland judar, medan stort sett ingen anser att det är vanligare bland andra. Samma relation gör sig, om än något mindre markant, gällande med avseende på självmedvetenhet, intelligens, prålighet och sparsamhet. När det gäller egenskaperna paranoia och tolerans och respekt för andra anser en betydande andel av medlemmarna i de judiska församlingarna också att detta är mer utmärkande för judar än för andra, men när det gäller dessa förhållanden är det också en liten andel som anser att dessa egenskaper är mer utmärkande för andra än för judar. Den hållning som en betydande andel av de judiska församlingsmedlemmarna menar är mer utmärkande för andra än för judar är att vara politiskt vänsterorienterad.

På en rad områden som har att göra med hur man relaterar sig till andra människor visar det sig ännu mer markant att det överväldigande flertalet av medlemmarna i de judiska församlingarna anser att judar inte skiljer sig från resten av befolkningen. Det gäller sådant som tvivelaktig affärsetik, omsorg om miljön, respekt för lag och ordning, stöd för kvinnans rättigheter, rasfördomar och djup religiös övertygelse. 
Samhörighetskänsla är däremot något som medlemmarna i de judiska församlingarna menar att i hög grad utmärker just judar. Djup religiös övertygelse är också något en betydande andel av medlemmarna anser att det finns mer av bland judar än bland andra, medan det när det gäller omsorg om miljön, stöd för kvinnans rättigheter och i synnerhet skilsmässor är fler som uppfattar detta som något som är mer utmärkande för den övriga befolkningen än för judar.

De flesta av respondenterna anser inte att judar, just för att de är judar, i särskild grad bör bidra till välgörande ändamål, inte heller att judar mer än andra bör hjälpa folk som diskrimineras. Men så många som mellan var tredje och varannan tycker dock att judar, just för att de är judar, faktiskt har ett särskilt ansvar, särskilt att hjälpa folk som diskrimineras.

Den mycket starka särställning medlemmarna tillskriver judar när det gäller samhörighetskänsla harmonierar med den redan gjorda iakttagelsen att det att vara jude av medlemmarna primärt uppfattas som en fråga om folktillhörighet. Betyder det också att medlemmarna tycker att i kritiska situationer kan judar bara lita på andra judar? Nej, det är faktiskt betydligt fler som tar avstånd från det påståendet än som instämmer i det. Det visar sig också, inte överraskande, att de som endast har en liten andel judar bland sina närmaste vänner i högre grad tar avstånd från påståendet än dem vars närmaste vänner huvudsakligen utgörs av judar. Men även bland dem som stort sett inte har judiska vänner instämmer en av fem i påståendet att i kritiska situationer kan judar bara lita på judar.

Till skillnad ifrån hur man upplever att staten Israel framställs i pressen upplever medlemmarna i allmänhet inte att judar i särskild grad blir orättvist behandlade $i$ massmedia. Endast var femte upplever att det sker ofta, medan över 70 procent menar att de endast sker ibland, sällan eller aldrig.

De allra flesta upplever att rasismen har ökat i Sverige under senare år, och också antisemitismen. Dock är andelen medlemmar som upplever att antisemitismen har ökat mindre än andelen som upplever att rasismen generellt har ökat i Sverige. Inte desto mindre anger så många som varannan medlem i de judiska församlingarna att de någon gång personligen har varit utsatta för antisemitism i Sverige, och hälften av dessa, dvs. ca var fjärde medlem, har blivit det under de allra senaste åren.

\section{Diasporans dialektik}

Judendom kan beskrivas som en "lagreligion". I judiska texter betecknas det som vi i Sverige med vårt kristet färgade språkbruk kallar "religionen" - ett begrepp som vi redan konstaterat inte har någon direkt motsvarighet i biblisk hebreiska - omväxlande för "läran" och »lagen«. I Toran, dvs. de fem Moseböckerna, som utgör kärnan i den hebreiska bibeln, kan man, som vi redan tidigare noterat, räkna sig fram till att det finns 613 olika mitzvot (påbud/»lagaru) som anger vad man som jude skall, respektive inte får göra. ${ }^{40} \mathrm{I}$ huvudsak syftar de till att reglera det vardagliga livet, i synnerhet samvaron mellan människor. I judendomen är det människans vandel och samvaro med

40 Se fotnot 21 . 
sina medmänniskor i familj, vardagsliv och samhälle här på jorden som står i centrum.

Men samtidigt lever man alltså i en värld där det är andra: kejsaren, kungen, diktatorn, eller den etnisk-kulturella majoritetens folkvalda politiska företrädare som stiftar lagar och ser till att dessa, som ibland står i direkt strid med de judiska ${ }^{41}$, efterlevs.

Detta är utgångspunkterna - vad leder de till? Det ligger inte fjärran att förmoda att det förhållandet att judar i diasporan alltid utgjort en religiöst och kulturellt avvikande minoritet i de samhällen där de bott har lagt grunden för ett särskilt förhållningssätt till samhälleliga makthavare och politisk maktutövning. Diasporatillvarons innebörd och framtidsperspektiv är också ett livligt diskuterat ämne inom samtidens judenhet (t.ex. Arendt \& Feldman 1978, Aviv \& Shneer 2005, Bauman 1998, Ehrlich 2009, Marienstras 1975, Vital 1990, Wasserstein 1996, Wettstein 2002). Flera av dessa verk tecknar huvudsakligen pessimistiska perspektiv beträffande diasporan som överlevnadsduglig livsform. Men det har också, inte minst under senare år, vuxit fram analyser (t.ex. Dencik 2007a, Marienstras ibid., Pinto 1999, Webber 1994) som tvärtom visar på de särskilda och positiva kvaliteter och livsperspektiv som diasporaexistensen erbjuder, inte bara för de judar som är direkta bärare av den, men också för samhället i stort, särskilt det europeiska. En av dem som mest eftertryck-

41 Jfr. förbudet att slakta djur enligt de judiska rituella föreskrifterna (shechita) i Sverige i dag. I Sverige infördes detta förbud 1937. Sverige är idag det enda land inom den Europeiska Unionen som upprätthåller ett sådant förbud. ligt pekat på just detta är den icke-judiske tjeckiske författaren Milan Kundera som i en uppmärksammad essä betitlad "Centraleuropas tragedi« publicerad på svenska i tidskriften Ord\&Bild skriver om judarnas roll innan Förintelsen i den centraleuropeiska kultur Kundera själv räknar som sin. För Kundera står det judiska inslaget i detta Europa som sinnebilden för det bästa inom hela den europeiska kulturtraditionen:

"Ingen del av världen har präglats så djupt av det judiska geniet som Europa. Främlingar överallt och överallt hemma, höja över nationstvisterna, har judarna varit det viktigaste kosmopolitiska och integrerande elementet $i$ Europa på 1900-talet, dess intellektuella cement, en förtätning av dess ande, skapare av dess andliga enhet. "(Kundera 1983)

En central maxim i den judiska texttraktat som mest konsekvent är ägnad åt etiska frågor, Pirkei Avåt, (Fädernas tänkespråk ${ }^{42}$ )

42 Pirkei Avåt är en sammanställning av rabbinska tänkespråk och maximer från vad som i judiska sammanhang kallas Mishna-perioden. Mishna är den första nedskrivna sammanställning av det som inom judendomen går under namnet "den muntliga toran" (lagen eller läran) som enligt legenden överlämnades av Gud till Moses samtidigt som han på Sinai berg mottog stentavlorna och den skrivna toran. Den muntliga lagen/ läran innehåller förklaringar till den skrivna och är lika giltig som denna. Mishna redigerades samman utifrån de rabbinska diskussioner som fördes i diasporans första århundraden (fr ung. år 70 - år 200 i vår tideräkning). Mishna utgör den centrala del av Talmud som under de efterföljande tre århundradena föranledde de rabbinska kommentarer som senare blivit nedtecknade i den del av Talmud som kallas Gemara. 
och som utförligt diskuteras i Talmud lyder: Älska arbete, avsky makt och undvik överheten. Det är den del av denna maxim som tillsäger läsaren (juden) att inte bli för upptagen av makt och/eller få ett för intimt förhållande med de härskande makthavarna som särskilt intresserar oss här.

För diasporans judar har det alltid inneburit både en frestelse och en risk att närma sig de världsliga makthavarna: en förklaring som ges i Talmud till den uppmaning vi här diskuterar är att den som kommer för nära makthavarna får deras ögon på sig och därmed utsätter sig för deras godtycke; därigenom kan de råka ut för att berövas både sina ägodelar och sitt liv. En annan tolkning som ges är att den som står i makthavares gunst lätt kan förhäva sig och förledas att föreställa sig att själv vara en del av härskarna. Men makthavare är förrädiska, lyder en kommentar i Talmud: »även om de till en början öppnar sina dörrar för honom (juden) kan detta till slut komma att bli fatalt för honom « ${ }^{43}$

Som citaten ovan visar är ett element i det diasporajudiska förhållningssättet misstro mot makthavare - om inte nödvändigtvis mot de aktuellt rådande makthavarna så åtminstone principiellt och på lång sikt. Ett annat inslag i det diasporajudiska förhållningssättet till världsliga makthavare är ödmjukhet. Inte för att detta skulle vara klädsamt eller något i den stilen, utan helt enkelt för att man vet att man, som den ofta lilla minoritet man är, aldrig kan komma att besitta sådan makt, och att det vore

43 Kapitel $11 \mathrm{i}$ textsamlingen Avåt de rabbi Nathan. utsiktslöst att genom egen maktutövning söka få samhället inrättat efter ens egna ideal och värderingar. ${ }^{44}$

I stället för att söka vinna makt, blir konklusionen att det gäller att etablera fredliga samarbetsrelationer med de världsliga ickejudiska makthavarna. Redan Jeremia säger till judarna i den babylonska fångenskapen "Och söken den stads bästa, dit jag har fört eder bort i fångenskap, och bedjen för den till Herren; ty då det går den väl, så går det ock eder välı (29:7). Detta formulerades av de första judiska lärde i den babylonska exilen som dina de-malkhuta dina kungadömets lag är lagen, dvs. att det är de världsliga makthavarnas lagstiftning som skall gälla som lag också för den enskilde juden. Denna princip upphöjdes av senare tiders rabbiner till judisk lag. Således gav de en halachisk (dvs. enligt judisk religiös lag) grund för judarna att lyda icke-halachiska lagar. Och därigenom inte endast lämnades maktutövningen åt de icke-judiska makthavarna - detta legitimerades också enligt judisk lag. Michael Walzer et al. hävdar i deras bok The Jewish Political Tradition från år 2000 (s. 432) att detta "gave rise to what might be called a theory of submission". Frågan gäller därefter inte om "kungadömets laguskall gälla, men hur långt denna maxims giltighet i varje läge skall få sträcka

44 Simon Dubnow, rysk-judisk historiker och den moderna judenhetens främsta diasporateoretiker uttrycker det i en essä betitlad Autonomism så: »... In view of its condition in the Diaspora, Jewish nationality cannot strive for territorial or political isolation, but only for social and cultural autonomy" (citerat ur Mondes-Flohr \& Reinhart 1980 s. 337). 
sig - och hur man skall fastställa den gränsen. Alltså inte om att strida om makt, men om hur man skall relatera sig till den. Inte om att försöka härska, men om att manövrera sig till ett utrymme i vilket man kan behärska sin underordning.

För att vinna det egna folkets stöd eller medgivande för detta - något som redan $\mathrm{i}$ de klassiska rabbinska diskussionerna förutsattes vara nödvändigt - måste man få makthavarens maktutövning att basera sig på åtminstone ett minimum av rättfärdighet. I det låg framför allt två ting: för det första att lagarna eller maktutövningens principer skulle göras explicita - i motsättning till att vara godtyckliga - så att man visste vad man hade att rätta sig efter; för det andra att de skulle gälla lika för alla - i motsättning till att vara öppet diskriminerande. Bara med detta uppfyllt kunde principen dina de-malkhuta dina upprätthålla sin giltighet. Mer kunde man som den lilla judiska minoritet man var oftast inte kräva - i själva verket kunde man i allmänhet inte heller förvänta sig mer av samhällets ickejudiska makthavare.

Alltså: snarare än att söka vinna maktpositioner har det typiskt diasporajudiska förhållningssättet till samhällets makthavare bestått i att lägga sig vinn om att etablera fungerande relationer till dem; snarare än att söka konflikt med dem, har det typiska blivit att vårda sig om att ha ett gott förhållande till dem; hellre konversation än konfrontation, bättre att kompromissa sig fram till ett modus vivendi än att gå under i en heroisk hjältedöd.

Den minoritet som lever på en "främmande» makthavares nåder är alltid i en prekär situation. Vad kan man göra för att i sin utsatthet uppnå så stor säkerhet som möjligt? Hur skall man etablera ett så gott förhållande som möjligt till de härskande makthavarna? Det var sådana frågor judar i diasporan hade att ta ställning till. Svaret blev ofta: att positionera sig så att man kom att uppfattas som nyttiga, behövda, bidragande till samhällets välstånd och utveckling. Ibland som finansiärer av makthavarnas expansionsplaner och krigsäventyr, ibland som specialiserade hantverkare och rådgivare, som vägröjare för handelsförbindelser, som introduktörer av industriella och teknologiska nymodigheter och senare, i modern tid, genom entrepenörskap och väsentliga bidrag till värdlandets vetenskapliga och kulturella utveckling. Till det sistnämnda har den judiska traditionens starka betoning på att man skall förkovra sin lärdom och ägna sig åt studier starkt bidragit.

Att man i alla de frågor som inte är helt centrala i halakha både bör och kan vara tvungen att följa »kungadömets lag» behöver i och för sig inte vålla svåra kval. Men hur skulle man som jude förhålla sig när »kungadömets lag" kommer i direkt strid med den lag "konungarnas konung", dvs. Gud har instiftat? Dvs. när den ickejudiske makthavaren/lagstiftaren sträcker sin jurisdiktion utöver den sekulära sfären till att också söka reglera centrala delar av den judiska gruppens religiösa liv? Om det sker - och det har skett flera gånger i historien - tvingas judar till isura, som det heter på hebreiska, dvs. till att göra vad som för dem är religiöst förbjudet. I värsta fall t o $\mathrm{m}$ till att helt överge sin religiösa övertygelse genom att tvångskonverteras till härskarfolkets religion. När detta stod för dörren var 
flykt den enda utvägen - om ens den möjligheten stod till rådighet. Den judiska historien rymmer flera sådana händelser. Den kanske mest välkända och för vår moderna tid ännu avgörande är utdrivningen ur alAndalus år 1492. ${ }^{45}$ Under ghetto-judendomens tid, dvs. innan upplysningsepoken och uppkomsten av den moderna nationalstaten var påtvungen isura förmodligen inte ett frekvent återkommande problem: inom ghettot fick judar i allmänhet leva enligt sina egna lagar. ${ }^{46}$ Men med den moderna nationalstatens och senare också demokratins födelse kom statsmakten att utsträcka sitt herravälde över olika samhällsgruppers civila sfär långt utöver vad som tidigare gällt. Ett signifikativt yttrande fällde greven av Clermont-Tonnerre

45 Då stora grupper judar i hast tvingades lämna iberiska halvön för att undkomma den kastilianska drottning Isabellas erövringståg och krav på judarna att konvertera till kristendomen. De flyende fick så småningom sin tillflykt i nordafrika och osmanska riket där de ofta behöll sitt medeltidsspanska modersmål, kallat ladino, och utvecklade sin egen sefardiska (till skillnad från den ashkenasiska tyska/östeuropeiska) judiska kulturen. Samma år, 1492, gav sig Christoffer Columbus ut på den resa som skulle "upptäcka» Amerika. Enligt några teorier (Wiesentahl 1973) var detta i själva verket ett försök av "smygjuden“ Columbus att upptäcka en ny flyktväg och en tillflyktsort för sina förtvivlade judiska landsmän.

46 Dock ofta utsatta för kränkningar och antijudiska upplopp - inte minst i samband med samhälleliga kriser och kristna högtider som påsken, då antijudiska sentiment väcktes och inte sällan kanaliserades i övergrepp mot ghettots eller shtetlns (byns/småstadens) judiska befolkning. den 23 december 1789 från talarstolen i den konstituerande nationalförsamlingen under franska revolutionen: "Judarna skall som nation nekas allt, men som individer garanteras allt «. ${ }^{47}$ Alltså: som enskild individ skall juden ha samma medborgerliga rättigheter som andra medborgare. Mot att judarna samtidigt förnekas rätten att som gemenskap tillvarata och manifestera sin "nationella" (som i detta sammanhang betyder kulturella) särart.

När i samband med de nationella moderniseringsprojekten under 1800-talet och början av 1900-talet t.ex. allmän värnplikt (som skulle innebära svårigheter att följa de religiöst betingade judiska levnadsreglerna) och civila äktenskaps- och skilsmässolagar och liknande infördes i flera nationalstater fick rabbinerna stora problem med att hantera detta. Var skulle gränsen sättas för den sekulära maktens legitima mandat att reglera den enskilde judens livsföring? Genom det fortgående moderniseringsprojektet blev gränsdragningen mellan statsmakt och olika medborgargrupperingars relativa civila autonomi allt mer uppluckrad. Efterhand som den moderna sekulära välfärdsstaten och det demokratiska systemet utbyggdes vidgades också principen om dina de-malkhuta dina.

Men därmed har den judiska gruppen inte uppgivit att hävda sin rätt till kulturell egenart och viss civil autonomi. Sättet att under moderna samhällsförhållanden vinna och upprätthålla detta går genom förhand-

47 Se P. Mendes-Flohr \& J. Reinharz (eds.) (1980) The Jew in the Modern World. A Documentary History. Oxford: Oxford University Press, p.104. 
ling med den sekulära statsapparaten ${ }^{48}$ och de icke-judiska makthavarna i samhället. I riktigt skärpta lägen när och om »kungadömets lag« kommer i direkt motstrid med den lag »konungarnas konung» har instiftat måste en jude dock i sista instans tillåta »kungadömets lag« att bli utslagsgivande. Ty det mest väsentliga för judendomen, mer centralt än att till varje pris följa t o $\mathrm{m}$ gudomligt givna rituella lagar, är även för fromma judar att rädda och bevara liv. Om det för att kunna göra det krävs att bryta »Guds lag« är det inte bara $\mathrm{OK}$ att göra det, det är t o $\mathrm{m}$ imperativt att temporärt göra det. Principen kallas i den judiska tanketraditionen Pikuach nefesh ("att säkerställa en själ $\approx$ att rädda ett livu) och ges en vid tolkning - t.ex. att gravida och sjuka bör äta även om det är påbjudet att fasta under Jom Kippur, Försoningsdagen, den »heligaste» av alla judiska helger. Att rädda en människas liv (också sitt eget) ges prioritet över allt annat, också över att följa "lagen" om det behövs.

I boken Shulamits väg. Om makt och frihet $i$ judiskt perspektiv (1998) undersöker bokens författare Per Molander "vilka möjligheter den svagare parten i en maktrelation har att överleva med bibehållen integritet" - och tillägger: "Åtskilliga har överlevt genom att ge upp sin integritet" (s. 7). Molander arbetar sig genom den tunga historiemassan fram till att relationerna mellan det judiska folket och omvärlden på sällsynt tydligt sätt illustrerar den inneboende instabiliteten i varje maktrelation. Den judiska erfarenheten är visserligen extrem

48 För en internationell orienterad diskussion om sekulariseringens politiska betydelse, se Kosmin \& Keysar 2007. konstaterar Molander, men "ur det judiska folkets varierande och överlag framgångsrika strategier i relation till övermakten har vi alla något att lära» (s. 8). Den centrala frågan är hur det kan komma sig att »trots förtryck och fragmentering har den judiska civilisationen överlevt, med bibehållen integritet. Hur har detta varit möjligt? Hur har denna i de flesta möten svagare part funnit sin väg?» (s. 265).

Molander svarar själv: "Nyckelordet är rörlighet. Det är kravet på yttre geografisk rörlighet som under århundraden odlat fram en inre, intellektuell rörlighet... rotlösheten var påtvingad, och rörligheten ett naturligt svar» (s. 281).

Häri ligger upprinnelsen till vad jag vill kalla diasporans dialektik. Det är genom denna som det judiska förhållningssättet till makt, maktutövning, maktlöshet och utsatthet har utformats och blivit till ett slags generaliserat och internaliserat diasporajudiskt förhållningssätt. Ett förhållningssätt som så småningom också lagt grunden för judars relativt goda integration i det moderna samhället, som i dagens Sverige.

Rörligheten har blivit en av det judiska folkets främsta tillgångar - det är en av historiens ironier, konstaterar Molander. Den både har sin förutsättning i, och har i sin tur lett till

"den i grunden öppna strukturen hos den judiska tron och kulturen (som) kontrasterar skarpt mot de bitvis längtgående och rigida reglerna för vardagslivets organisation. Den kritiska attityden har genomsyrat förhaillandet till högre makter och varit inbyggd i de procedurer som styrt regelverkets utveckling. Den yttre organisationen har varit polycentrisk, vilket också bidragit 
till det troende kollektivets lärande kapacitet. De stela regler som präglat vardagslivet har framför allt tjänat att befästa identiteten. Det är (i) denna särpräglade kombination av flexibilitet $i$ det väsentliga och rigiditet när det gäller detaljer som förklaringen till judendomens överlevnad ligger." (ibid. s. 271)

Överlevnadsstrategien har stått på två ben: allianser och rörlighet. Det är i växelspelet däremellan som det jag i denna artikels rubrik kallat "konsten att vara judisk" har utvecklats. Ett sådant förhållningssätt har inte bara kunnat överleva, det har varit förutsättningen för själva överlevandet och har i dagens samhälle t o $\mathrm{m}$ blivit en generell nödvändighet för många fler grupper än den judiska: „Världen har... blivit mera judisk avslutar Molander sin bok (s. 315).

Ett annat och mer allmängiltigt sätt att säga det är att i dagens samhälle är distinktionen mellan makt och maktlöshet mindre klar och entydig och mer flytande än vad den traditionellt varit. Vi måste alla vara mer rörliga, mer öppna för nya allianser, mer flexibla och därför också mer måna om att skydda och bevara vår egen integritet än vad som tidigare varit påkallat. Kort sagt: leva enligt diasporans dialektik.

\section{Referenser}

Alter, R. (1991) Necessary Angels. Tradition and Modernity in Kafka, Benjamin and Sholem. Cambridge: Ma. Harvard University Press.

Arendt, H. \& Feldman, R. H. (eds.) (1978) The Jew as pariah. Jewish identity and politics in the modern age. New York: Grove Press, distributed by Random House.

Aviv, C. \& Shneer, D. (2005) New Jews: The End of the Jewish Diaspora. New York: New York University Books.

Bauman, Z. (1998) "Allosemitism: Premodern, Modern, Postmodern«. In Bryan Cheyette \& Laura Marcus (eds.) Modernity, Culture and 'The Jew'. Stanford: Stanford University Press and Wiley/Polity Press.

Benjamin, W. (1950) "Über den Begriff der Geschichte». Die Neue Rundschau, vol. 61, pp. 560-70.

Berggren, H. \& Trägårdh, L. (2006) Är svensken människa? Gemenskap och oberoende $i$ det moderna Sverige. Stockholm: Norstedts.

Bredefeldt, R. (2008) Judiskt liv i Stockholm och
Norden. Ekonomi, identitet och assimilering 1850-1930. Stockholm: Stockholmia Förlag.

DellaPergola, S. (1999) World Jewry Beyond 2000: The Demographic Prospects. Oxford: Oxford Centre of Judaic and Hebrew Studies.

Dencik, L. (2007a) Judendom i Sverige - en sociologisk belysning. Uppsala: Swedish Science Press.

Dencik, L. (2007b) „Från mosaiskt majoritetskramande till judiskt minoritetsmedvetande». Judisk Krönika 75 år, december 2007.

Dencik, L. \& Marosi, K. (2007) Judiskt liv i Sverige - identitet, levnadsvanor och attityder bland medlemmarna $i$ de judiska församlingarna $i$ Sverige vid ingången till 2000-talet. Stockholm: Judiska Centralrådet.

Ehrlich, M. A. (ed.) (2009) Encyclopedia of the Jewish Diaspora: Origins, Experiences, and Culture. Santa Barbara, Ca. ABS-CLIO, LLC.

Espersen, S. (2009) "Se at blive danskere». Politiken den 19 juni.

Fackenheim, E. (1994)[1982] To Mend the World: Foundations of Future Jewish Thought. New 
York: Schocken Books.

Fisher, D. (1996) Judiskt liv. En undersökning bland medlemmar $i$ Stockholms judiska församling. Uppsala: Megilla-förlaget.

Gitelman Z., Kosmin B. \& Kovacs A. (eds.) (2003) New Jewish Identities: Contemporary Europe and Beyond. Budapest: Central European University Press.

Goldscheider, C. \& Zuckerman, A. (1984) The Transformation of the Jews. Chicago: University of Chicago Press.

Gruber, R. E. (2002) Virtually Jewish. Reinventing Jewish Culture in Europe. Berkeley: University of California Press.

Jakubowski, J. (red.) (1993) Judisk Identitet. Stockholm: Natur och Kultur.

Jakubowski, J. (2009) Spår av lamed. Stockholm: Atlantis.

Klein, G. (1987) Ateisten och den heliga staden: möten och tankar. Stockholm: Bonnier.

Kosmin, B. \& Keysar, A. (eds.) (2007) Secularism and Secularity: Contemporary International Perspectives. ISSSC, Hartford, CT.

Kundera, Milan (1983) "Centraleuropas tragedi». Ord\&Bild, nr. 4, s. 2-19.

Lustig, S. \& Leveson. I. (eds.) (2006) Turning the Kaleidoscope: Perspectives on European Jewry. Oxford: Berghahn Books.

Marienstras, R. (1975) "The Jews of the Diaspora or the Vocation of a Minority". European Judaism 9(2).

Mendes-Flohr, P. \& Reinharz, J. (eds.) (1980) The Jew in the Modern World. A Documentary His- tory. Oxford: Oxford University Press.

Molander, P. (1998) Shulamits väg. Om makt och frihet i judiskt perspektiv. Stockholm: Atlantis.

Pettersson, T. \& Esmer, Y. (eds.) (2008) Changing Values, Persisting Cultures: Case Studies in Value Change. Leiden: Brill Academic Publishers.

Pinto, D. (1999) »Towards an European Jewish Identity". Golem Europäisch-Jüdishes Magazin.

Schnapper, D. (1980) Juifs et Israélites. Paris: Gallimard.

Sterner Carlberg, M. (1994) Gemenskap och överlevnad: om den judiska gruppen i Borås och dess historia. Göteborg: Göteborgs universitet, Institutionen för socialt arbete.

Vital, D. (1990) The Future of the Jews: A people at the Crossroads? Cambridge, Mass: Harvard University Press.

Walzer M., Loberbaum M., Zohar N. \& Loberbaum Y. (eds.) (2000) The Jewish Political Tradition. Vol I. Authority. New Haven, Ct.: Yale University Press.

Wasserstein, B. (1996) Vanishing Diaspora: The Jews in Europe Since 1945. Cambridge: Ma. Harvard University Press.

Webber, J. (ed.) (1994) Jewish Identities in the New Europe, London: Littman Library of Jewish Civilisation.

Wettstein, H. (ed.) (2002) Diasporas and Exiles. Varieties of Jewish Identity. Berkeley: University of California Press.

Wiesenthal, S. (1973) Christofer Columbus' hemliga mission. Stockholm: Berghs förlag. 


\section{Summary}

\section{The dialectics of Diaspora On the art of being Jewish in Swedish modernity}

The Jews have been relatively successful in keeping and developing their specific cultural traditions. At the same time they have also been quite successfully integrated in modern Swedish society. What factors in the legacy of the Jewish people have been decisive for this? What is the significance of the fact the Jewish people during two millennia have lived in a Diaspora? More specifically: does the predicament of living as a minority in the Diaspora generate specific attitudes and behavioral styles in relation to power holders in society and to social power generally? The article proceeds in seven sections:

(1) Religion and Peoplehood: Jews in Sweden primarily perceive the Jewish group as "part of the Jewish people». Only a tiny minority of the Jews in Sweden today perceive the Jewish group "primarily as religious group». (2) Conditions for "a Jewish way of relating to life : Implications of living as a Diaspora people and of a "Talmudic attitude", even if secular, are seen as contributing to "a Jewish way of relating to life». (3) The contemporary Jewish scene in Sweden: It is concluded that the Jews in Sweden constitute an actual civil society. (4) From "Mosaic majority-embracing to Jewish minority consciousnessu: Implications of being a minority in a pre-emancipatoric epoch are compared to being so in the present post-emancipatoric era. (5) Excursion: assimilation or integration? The concept of integration is elaborated. Many contemporary immigrants in Sweden and Denmark are neither assimilated nor integrated into society. In contrast to that, it is found that one of the keys to the relatively successful integration of Jews has been their "double integration" into, on the one hand, their Jewish heritage and culture and, on the other hand, into Swedish society. (6) Jews and non-Jews: Data from a national survey of members of the Jewish communities in Sweden indicate that they have an open attitude towards their nonJewish environment. On the whole they do not perceive themselves as fundamentally different from the majority of non-Jewish Swedes. Still one quarter of the Jews report that they personally have experienced antiSemitism in Sweden during the last few years. (7) The dialectics of Diaspora: The Diaspora-Jewish attitude of relating to social power is traced back to the Jews' historic experiences and texts. Mobility, alliances and the allowance for a high degree of flexibility with respect to one's tradition are found to be mechanisms that provide for "the art of being Jewish" in the Diaspora - which is also what is more required than before by all citizens in modern societies. 